\title{
The influence of $17 \beta$-estradiol on annexin 1 expression in the anterior pituitary of the female rat and in a folliculo-stellate cell line
}

\author{
Evelyn Davies, Selma Omer, John F Morris and Helen C Christian \\ Department of Physiology, Anatomy and Genetics, University of Oxford, South Parks Road, Oxford OX1 3QX, UK \\ (Requests for offprints should be addressed to H C Christian; Email: helen.christian@anat.ox.ac.uk)
}

\begin{abstract}
Annexin 1 (ANXA1) is a $\mathrm{Ca}^{2+}$ - and phospholipid-binding protein that plays an important role as a mediator of glucocorticoid action in the host-defence and neuroendocrine systems. Sex differences in hypothalamo-pituitary-adrenal (HPA) axis activity are well documented and a number of studies have demonstrated that gonadal steroids act as regulators of HPA activity. The aim of this study was to investigate the effect of ovariectomy and $17 \beta$-estradiol replacement, and estrous cycle stage, on anterior pituitary ANXA1 content. The amount of anterior pituitary ANXA1 determined by western blotting varied with estrous cycle stage with a peak at estrus declining to a trough at proestrus. Ovariectomy resulted in a significant $(P<0 \cdot 05)$ decrease in anterior pituitary ANXA1 content.
\end{abstract}

Administration of $17 \beta$-estradiol $(1 \mu \mathrm{g} / 100 \mathrm{~g})$ significantly $(P<0 \cdot 01)$ increased anterior pituitary ANXA1 expression in the ovariectomized animals. In contrast, there was no change in pituitary ANXA1 content in response to $17 \beta$-estradiol in adrenalectomized and adrenalectomized/ovariectomized rats. Treatment of TtT/GF cells, a folliculo-stellate cell line, with 17 $\beta$-estradiol $(1 \cdot 8-180 \mathrm{nM})$ increased ANXA1 mRNA expression and increased the amount of ANXA1 protein externalized in response to a dexamethasone stimulus. These results indicate that $17 \beta$-estradiol stimulates ANXA1 expression in the anterior pituitary and in vivo an adrenal factor contributes to the mechanism of action.

Journal of Endocrinology (2007) 192, 429-442

\section{Introduction}

Sex differences in hypothalamo-pituitary-adrenal axis (HPA) activity are well documented and a number of studies have demonstrated that gonadal steroids act as regulators of HPA activity (Viau \& Meaney 1991, Freeman 1994, Carey et al. 1995). Changes in plasma corticosterone are associated with estrous cycle stage in rodents such that peak adrenocorticotrophic hormone (ACTH) and corticosterone levels are highest in the afternoon of proestrus (Carey et al. 1995), the time of maximal estradiol secretion (Freeman 1994). In addition, the stress responsiveness of the female HPA varies with the estrous cycle, with increased corticosterone release in response to stress occuring at proestrus (Viau \& Meaney 1991). Sexual dimorphism in corticosterone secretion is well established: female rodents display elevated corticosterone secretion in basal and some stress conditions relative to males (Critchlow et al. 1963). Furthermore, estrogen exerts stimulatory effects on stress-induced ACTH and glucocorticoid release, whereas testosterone acts to inhibit HPA activity (Seale et al. 2004). In addition, it is now evident that exposure to gonadal steroids influences HPA programming during perinatal development (Seale et al. 2005) and is responsible for the changes in the HPA responsiveness at puberty (Viau et al. 2005).

Annexin 1 (ANXA1) is a member of the annexin family of $\mathrm{Ca}^{2+}$ - and phospholipid-binding proteins (Moss \& Morgan
2004) that has been demonstrated to act as a mediator of glucocorticoid action in the inflammation and in the control of anterior pituitary hormone release (John et al. 2004). Functional studies have demonstrated a key role for ANXA1 in mediating certain acute, non-transcriptional inhibitory actions of the glucocorticoids on the release of ACTH (Taylor et al. 1995, 1997) and other pituitary hormones (reviewed in John et al. 2004). The effect of glucocorticoids in several tissues, including the anterior pituitary, is to cause externalization of ANXA1 from the cytoplasm to the outer cell surface where it is retained by a $\mathrm{Ca}^{2+}$-dependent mechanism (Chapman et al. 2002) and to induce ANXA1 synthesis (Philip et al. 2001). ANXA1 is expressed strongly in the S100-positive folliculo-stellate cells (FS cells) in the anterior pituitary (Traverso et al. 1999) and in vivo almost total loss of FS cell ANXA1 immunoreactivity occurs in adrenalectomized rats which is replenished upon glucocorticoid replacement (Ozawa et al. 2002). Functional and binding studies suggest that the glucocorticoid-induced translocation of ANXA1 via the ATP-binding cassette transporter ABCA1 (Chapman et al. 2003, Omer et al. 2006) is an important mechanism which enables the protein to access binding sites on the surface of the endocrine cells and thereby exert paracrine regulation on the release of $\mathrm{ACTH}$ and other pituitary hormones via surface binding proteins (Christian et al. 1997).

The role of ANXA1 has so far been studied almost exclusively in male rodents and it is not known how ANXA1 
varies with the estrous cycle of the rat and the female sex estrogen status. Our recent findings demonstrate that ANXA1 null mice exhibit sexual dimorphisms in HPA function and inflammatory responses (Hannon et al. 2003, Morris et al. 2006). The occurrence of gender-based differences in the susceptibility to a number of disease models in the rodent (Schuurs \& Verheul 1990, Homo-Delarche et al. 1991, Whitacre et al. 1998) has been attributed to complex interactions between the differential HPA axis activity and the immune system of male and female rats. In human subjects, a strong correlation exists between serum cortisol concentrations and ANXA1 expression in peripheral blood leukocytes (Mulla et al. 2005). Mulla et al. (2005) proposed that changes in leukocyte ANXA1 expression in human subjects may serve as an index of tissue sensitivity to glucocorticoids, and that such changes might contribute to autoimmune and inflammatory diseases associated with glucocorticoid dysregulation. It is therefore possible that gonadal regulation of ANXA1 expression may be of physiological significance in contributing to the etiology of the sexual dimorphisms in neuroendocrine and host-defence function and susceptibility to disease. In the present study, we have investigated the hypothesis that $17 \beta$-estradiol regulates ANXA1 expression in the anterior pituitary. We now report (1) the effects of ovariectomy and $17 \beta$-estradiol replacement in female rats, and (2) the effects of $17 \beta$-estradiol in a FS cell line, on ANXA1 expression.

\section{Materials and Methods}

\section{Drugs}

The following drugs were used: $17 \beta$-estradiol, dexamethasone sodium phosphate, and corticotropin releasing factor (CRF). $17 \beta$-estradiol $\left(\mathrm{E}_{2}\right)$ was dissolved directly in sesame oil for in vivo s.c. injection. Dexamethasone (Faulding Pharmaceutical plc, Leamington Spa, Warks, UK) and corticotrophin-releasing hormone (CRH; Bachem, Heidelberg, Germany) used in in vitro experiments were diluted directly into the incubation medium. All drugs and reagents were from Sigma Chemical Co. unless otherwise stated.

\section{Animals}

Adult female Sprague-Dawley rats (200 g) were purchased from Harlan Olac (Bicester, Oxon, UK) and were allowed to acclimatize for 2 weeks in the animal holding facility before experimentation. The Universities Federation for Animal Welfare (UFAW) Handbook on the Care and Management of Laboratory Animals was followed and the study was carried out under license in accordance with the UK Animals (Scientific Procedures) Act 1986. The rats were housed in groups offive per cage in a quiet room with $14 \mathrm{~h}$ light: $10 \mathrm{~h}$ darkness and temperature maintained at $20-21^{\circ} \mathrm{C}$; food was available ad libitum. All experiments were started between 0800 and $1000 \mathrm{~h}$ to avoid changes associated with the circadian rhythm. For estrous cycle studies, rats were smeared daily for 30 days between 0800 and $1000 \mathrm{~h}$. The smears were collected on glass slides, stained with toluidine blue, and examined under a light microscope. The cycle stage was estimated and only rats observed to be cycling regularly were chosen for study $(n=6$ rats used per cycle stage). Animals were killed by stunning and decapitation and the anterior pituitary glands removed. Trunk blood was collected and placed in chilled heparinized tubes for centrifugal separation $(2000 \mathrm{~g}, 10 \mathrm{~min}$ ) of plasma for subsequent assay of corticosterone. The uteri were weighed postmortem and in all cases weights were found to correlate with the stage of the estrous cycle.

\section{Rat ovariectomy and treatment with $17 \beta$-estradiol}

Adult female Sprague-Dawley rats $(200 \mathrm{~g})$ were anesthetized with Hypnorm/Hypnovel (1:1:2 dilution in water, $3 \mathrm{ml} / \mathrm{kg}$ ip; Janssen Pharmaceuticals, Oxford, UK) and subsequently either sham-operated (control) or bilaterally ovariectomized (OVX). In further experiments, subgroups of rats were bilaterally adrenalectomized (ADX), OVX, or bilaterally ADX and OVX. The animals were allowed to recover postoperatively for 7 days, and on day 8 after surgery groups of rats $(n=6$ rats) received a s.c. injection of vehicle (sesame oil), or $17 \beta$-estradiol $(1 \mu \mathrm{g} / 100 \mathrm{~g}$ body weight), 24 and $12 \mathrm{~h}$ before sacrifice on day 9 . The concentration and regimen of $17 \beta$-estradiol treatment has been reported in the literature to produce physiological concentrations of plasma $17 \beta$-estradiol $(163 \mathrm{pg} / \mathrm{ml})$ in the SpragueDawley rats (Young et al. 2001). Animals were killed by stunning and decapitation and the anterior pituitary glands removed. Trunk blood was collected and placed in chilled heparinized tubes for centrifugal separation $(2000 \mathrm{~g}, 10 \mathrm{~min})$ of plasma for subsequent assay of ACTH and corticosterone. Uteri were also removed and weighed.

\section{Detection of $A N X A 1$ by SDS-PAGE and western blot analysis}

ANXA1 was extracted from pituitary tissue and TtT/GF cells by sonication (25 Hz, 20 s, Soniprep 150, MSE, Crawley, UK) on ice in EDTA $(10 \mathrm{mM})$ containing Triton X-100 (1\% v/v) as described previously (Chapman et al. 2003). The protein content of each sample was determined using the Pierce BCA protein assay (Pierce, Macclesfield, Cheshire, UK). The samples were then analyzed for ANXA1 by SDS-PAGE and subsequent western blotting using a well-characterized polyclonal antiANXA1 antibody (raised in sheep against the full-length human recombinant ANXA1 and diluted in the ratio of 1:10 000; Chapman et al. 2003) as a probe. Normalization was conducted by gently striping the blots $(0 \cdot 2 \mathrm{M}$ glycine $(\mathrm{pH} 2 \cdot 8), 1 \mathrm{~h}$, room temperature) and re-blocking and re-probing with a mouse $\beta$-actin antibody (1:10 000, $1 \mathrm{~h}$, room temperature) and mouse secondary antibody $(1: 5000,1 \mathrm{~h}$, room temperature; both AbCam, Cambridge, UK). Intensity values were normalized relative to control values. The blots were scanned using a flatbed scanner (HP Scanjet 5200 with Adobe Photodeluxe Business 
Edition v1.1) and the band intensity analyzed using the TINA software program (TINA version 2.10, Raytest Isotopenmessgeraete $\mathrm{GmbH}$, Straubenhardt, Germany).

\section{Secretion of ACTH in vitro by anterior pituitary segments}

Rat anterior pituitary segments from (1) OVX- and $17 \beta$-estradiol-treated OVX females or (2) proestrus and estrus females were distributed randomly (1 segment/well) in the wells of 24-well tissue culture plates (Costar, Cambridge, MA, USA) and incubated at $37^{\circ} \mathrm{C}$ for $90 \mathrm{~min}$ in $1 \mathrm{ml}$ incubation medium $(1 \%(\mathrm{vol} / \mathrm{vol})$ aprotonin (Bayer Corp., Saffron Walden, Essex, UK) and 1\% (vol/vol) penicillin/streptomycin in oxygenated Earles' Balanced Salt Solution ( $\mathrm{pH} 7 \cdot 4)$; phenol red-free) under a humidified atmosphere saturated with $95 \% \mathrm{O}_{2}, 5 \% \mathrm{CO}_{2}$. The medium was changed after 1 and $1.5 \mathrm{~h}$. The segments were then incubated for a further $1 \mathrm{~h}$ in medium containing CRH $(10 \mathrm{nM})$; controls were exposed to an equal volume $(1 \mathrm{ml})$ of medium alone. Where appropriate dexamethasone $(0 \cdot 1 \mu \mathrm{M})$ was included in the medium throughout both the pre- and final incubation periods. Medium from the final incubation was collected and stored in aliquots $\left(300 \mu \mathrm{l},-20^{\circ} \mathrm{C}\right)$ for subsequent measurement of immunoreactive (ir) ACTH.

\section{ACTH ELISA and corticosterone RIA}

ACTH was determined in duplicate by use of a commercially available ELISA (IDS Ltd, Boldon Colliery, Tyne and Wear, UK) according to the manufacturer's instructions. The assay sensitivity was $0.5 \mathrm{pg} / \mathrm{ml}$ and the inter- and intraassay coefficients of variation were $5 \cdot 8$ and $3 \cdot 1 \%$ respectively. Corticosterone was determined in duplicate by the use of a commercially available RIA (IDS Ltd) according to the manufacturer's instructions. The minimum detection level of the assay was $0.39 \mathrm{ng} / \mathrm{ml}$ and the intra- and interassay coefficients of variation were $10 \cdot 4$ and $12 \cdot 4 \%$ respectively. Dilution of samples provided a parallel displacement to the standards in both assays.

\section{TtT/GF cell incubations}

FS-like (TtT/GF) cells were maintained as described previously (Tierney et al. 2003) in a humidified incubator at $37^{\circ} \mathrm{C}, 5 \%$ $\mathrm{CO}_{2}$ and cultured in Dulbecco's modified Eagle medium (DMEM) DMEM-Hams-F12 medium (Invitrogen Ltd.), enriched with 15\% (v/v) fetal calf serum (PAA Laboratories Ltd., Yeovil, Somerset, UK), penicillin $(100 \mathrm{U} / \mathrm{ml})$, and streptomycin $(100 \mu \mathrm{g} / \mathrm{ml})$ in a $5 \% \mathrm{CO}_{2}$ humidified atmosphere. Plates (24 well) containing approximately 50000 cells/well were allowed to reach $80 \%$ confluence. The cells were then incubated either in incubation medium alone $(1 \%(\mathrm{vol} / \mathrm{vol})$ aprotonin (Bayer Corp.) and 1\% (vol/vol) penicillin/streptomycin in oxygenated Earles' Balanced Salt Solution ( $\mathrm{pH} 7 \cdot 4$ ) phenol red-free) or with graded concentrations of $17 \beta$-estradiol $(0 \cdot 18-1800 \mathrm{nM})$ for $24 \mathrm{~h}$. The duration of treatment of $24 \mathrm{~h}$ was initially selected as previous ANXA1 promoter-driven luciferase reporter gene studies in $\mathrm{TtT} / \mathrm{GF}$ cells have demonstrated increased luciferase expression in $24 \mathrm{~h}$ (Solito et al. 2003). In further time-course experiments, TtT/GF cells were exposed to $17 \beta$-estradiol (18 nM) for 3, 6, 12, or $24 \mathrm{~h}$. In addition, TtT/GF cells were incubated for $24 \mathrm{~h}$ either in medium alone, $17 \beta$-estradiol $(18 \mathrm{nM})$ alone, dexamethasone $(0 \cdot 1 \mu \mathrm{M})$ alone, or co-treated with $17 \beta$-estradiol $(18 \mathrm{nM})$ and dexamethasone $(0 \cdot 1 \mu \mathrm{M})$. At the end of each incubation, period cells were processed for western blot analysis of total ANXA1 expression. In order to investigate the effects of $17 \beta$-estradiol pretreatment on dexamethasone-induced externalization of ANXA1, control- and $17 \beta$-estradiol $(18 \mathrm{nM}, 24 \mathrm{~h})$-treated groups were subsequently incubated for $3 \mathrm{~h}$ either in incubation medium alone or with $0 \cdot 1 \mu \mathrm{M}$ dexamethasone sodium phosphate. The duration of 3-h treatment with dexamethasone is well established to stimulate ANXA1 externalization (Taylor et al. 1997, Chapman et al. 2003). At the end of the incubation period, cells were processed for western blot analysis of cell surface and intracellular ANXA1 expression. Cell surface ANXA1 was removed from the outer cell membranes by washing the tissue gently for $2 \mathrm{~min}$ in a solution containing 1 mM EDTA in PBS (0.05 M (pH 7-4); Oxoid Chemicals Ltd., Basingstoke, Hants, UK) which, by chelating $\mathrm{Ca}^{2+}$, releases ANXA1 into the medium from $\mathrm{Ca}^{2+}$-dependent cell surface binding sites.

Detection of estrogen receptor (ER) $\alpha$ and $E R \beta$ in TtT/GF cells by immunofluorescence microscopy

For immunofluorescence experiments, TtT/GF cells were seeded into eight-well glass chamber slides (Nalge Nunc International, Cambridge, UK) at a density of 5000 cells/well. The cells were either incubated in medium alone or stimulated with $180 \mathrm{nM}$ estradiol for $24 \mathrm{~h}$, then fixed in 3\% paraformaldehyde, $0 \cdot 05 \%$ glutaraldehyde $(5 \mathrm{~min})$, and permeabilized with $0 \cdot 2 \%$ Triton X-100 (in PBS at room temperature, $5 \mathrm{~min}$ ). Non-specific antibody binding sites were blocked with block buffer (3\% BSA in PBS; PBS-BSA) for $30 \mathrm{~min}$. The expression of $\operatorname{ER} \alpha$ was detected with a mouse monoclonal anti-ER $\alpha$ (prediluted, used neat; Dako, Ely, Cambs, UK) and ER $\beta$ with a rabbit polyclonal ER $\beta$ antibody (1:100; Oncogene, Nottingham, UK) overnight at $4{ }^{\circ} \mathrm{C}$ in PBS-BSA. Immunoreacted sections were then washed with PBS and incubated for $1 \mathrm{~h}$ at room temperature with fluorescein-conjugated anti-mouse or anti-rabbit IgG (Vector Laboratories, Burlingame, CA, USA). The chambers were rinsed with PBS and the nuclei counterstained for 5 min with TOPRO-3 (Molecular Probes, Eugene, OR, USA). Slides were mounted in Vectashield mounting medium (Vector Laboratories) and examined using a titanium crystal sapphire (TCS) confocal microscope (Leica Corp. Microsystems, Wetzlar GmbH, Germany). Non-specific staining and background were assessed by substitution of non-immune sera for primary antisera and incubation with $\mathrm{ER} \alpha$ and $\mathrm{ER} \beta$ antibodies previously absorbed with an excess 
of the respective receptor protein $(\mathrm{ER} \alpha$, Dako; $\mathrm{ER} \beta$, Oncogene).

\section{Real-time PCR}

Total RNA was isolated from pituitary tissue or TtT/GF cells using the RNeasy kit (Qiagen) following the manufacturer's instructions and treated with DNA-free DNAse (Ambion, Witney, UK) to remove traces of genomic DNA contamination. Three micrograms of tRNA from each sample were subsequently reverse transcribed using $1 \mu$ Moloney murine leukemia virus reverse transcriptase (Clontech), $2 \mu 110 \mathrm{mM}$ dNTP, $2 \mu 100 \mathrm{mM}$ dithiothreitol in a total volume of $20 \mu \mathrm{l}$. To measure cDNA levels, a threshold cycle $(\mathrm{Ct})$ was selected within the exponential phase of the amplification for all standards and samples. Standards were generated by serial dilutions of a cDNA pool from rat pituitary. A standard curve was generated by plotting standards against $\mathrm{Ct}$ values and sample values were read from this standard curve. ANXA1 expression was then detected and quantified by real-time PCR (QPCR) in $25 \mu \mathrm{l}$ reactions containing 12.5 $\mu \mathrm{l}$ Absolute QPCR mix (ABgene, Epsom, Surrey, UK), $0 \cdot 4 \mu \mathrm{M}$ of each of the ANXA1 primers (For primer 5'ATACAGATGCCAGGGCTTTGTATGA3'; Rev primer 5'TGGGATGTCTAGTTTCCACCACACA3 ${ }^{\prime}$ ), and $0 \cdot 25 \mu \mathrm{M}$ ANXA1 FAM/ TAMRA-dual-labeled probe (Sigma-Genosys) in a 96-well plate format. The QPCR assay was performed in an ABI PRISM 7700 (Applied Biosystems, Warrington, Cheshire, UK) and cycled as follows: initial enzyme activation at $95{ }^{\circ} \mathrm{C}$ for $15 \mathrm{~min}$ then 40 cycles of $95^{\circ} \mathrm{C}$ for $15 \mathrm{~s}$ and $60^{\circ} \mathrm{C}$ for $1 \mathrm{~min}$. The assays were normalized relative to an endogenous control, 18S rRNA (primers and probes from Applied Biosystems) and the results expressed as the amount of ANXA1 mRNA/18SRNA.

\section{Data analysis}

Semi-quantitative measures of ANXA1 protein expression were made by comparisons of western blot band optical densities (arbitrary units) to give a relative numerical guide to the ratios of the band intensities normalized to actin and their variance. Responses to steroids were calculated as a percentage of the corresponding vehicle control and expressed as the mean \pm S.E.M. ( $n=3$ gels); statistical comparisons between the normally distributed data from groups were made by ANOVA. Each of the studies was repeated thrice, and in all instances the data profile was similar. For hormone release studies, preliminary analysis by the Shapiro and the Wilkes test confirmed that the data were normally distributed. Subsequent analysis was done by ANOVA with post hoc comparisons by Scheffe's test. Since the rate of basal ACTH release in vitro varied between experiments, statistical comparisons were made within experiments only. Differences were considered significant if $P$ was $<0 \cdot 05$.

\section{Results}

Effect of ovariectomy and $17 \beta$-estradiol replacement on anterior pituitary $A N X A 1$ expression

In order to investigate the regulation of anterior pituitary ANXA1 content by $17 \beta$-estradiol in vivo, female rats were sham-operated or ovariectomized and treated with either vehicle or $17 \beta$-estradiol $(1 \mu \mathrm{g} / 100 \mathrm{~g}$ body weight (BW); $24 \mathrm{~h}$ ) and anterior pituitary ANXA1 measured by western blot analysis. ANXA1 was readily detectable in female anterior pituitary tissue by western blot analysis as a $37 \mathrm{~K}$ molecular band which corresponded to the native biologically active species of the protein. Western blot analysis demonstrated a significant $(P<0 \cdot 01)$ reduction in anterior pituitary ANXA1 total content following ovariectomy compared with sham-operated (Fig. 1A: OVX shown in western blot lanes 1 and 2 compared with sham-operated shown in lanes 3 and 4; densitometry shown in Fig. 1C). 17 $\beta$-Estradiol treatment of OVX females for $24 \mathrm{~h}$ caused a significant $(P<0 \cdot 01)$ increase in anterior pituitary ANXA1 content (Fig. 1A, 17 $\beta$-estradioltreated OVX lanes 5 and 6 versus vehicle-treated OVX lanes 1 and 2; Fig. 1C). Similarly, $17 \beta$-estradiol treatment of shamoperated females for $24 \mathrm{~h}$ also caused a significant $(P<0 \cdot 01)$ increase in anterior pituitary ANXA1 content (Fig. 1A, $17 \beta$-estradiol-treated sham-operated lanes 7 and 8 versus vehicle-treated sham-operated lanes 3 and 4; Fig. 1C). No change was observed in the amount of $\beta$-actin detected (Fig. 1B). Circulating corticosterone was significantly reduced $(P<0 \cdot 05)$ in OVX compared with sham-operated female rats (Fig. 1D) and in OVX animals corticosterone was significantly increased $(P<0 \cdot 01)$ in response to $17 \beta$-estradiol (Fig. 1D). No significant difference in circulating corticosterone was measured in sham-operated animals treated with $17 \beta$-estradiol (Fig. 1D) compared with vehicle. The basal corticosterone levels were high in these experiments and it is possible that the animals were stressed during the testing conditions. Surgery and treatments were indicated to have been effective as the uterine weights of the OVX rats were significantly $(P<0 \cdot 01)$ lower than sham-operated, and $17 \beta$-estradiol treatment of OVX rats caused a significant increase $(P<0 \cdot 05)$ in uterine weight such that there was no significant difference compared with the sham-operated uterine weights (Fig. 1E).

\section{Effect of adrenalectomy and combined adrenalectomy and ovariectomy on the stimulation of anterior pituitary $A N X A 1$ expression by $17 \beta$-estradiol}

In order to examine the potential role of the adrenal in the regulatory effects of $17 \beta$-estradiol on ANXA1 expression in OVX rats, the effect of adrenalectomy was investigated. Administration of $17 \beta$-estradiol $(1 \mu \mathrm{g} / 100 \mathrm{~g})$ to OVX animals induced a significant $(P<0 \cdot 05)$ increase in anterior pituitary ANXA1 mRNA (Fig. 2A) and protein (Fig. 2B) compared with vehicle-treated controls. As expected, adrenalectomy 
A

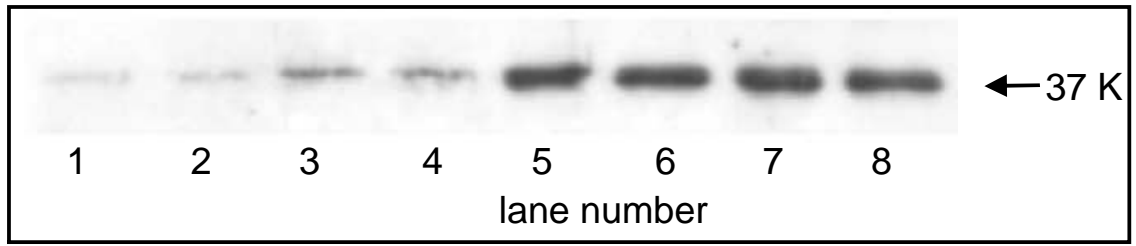

B

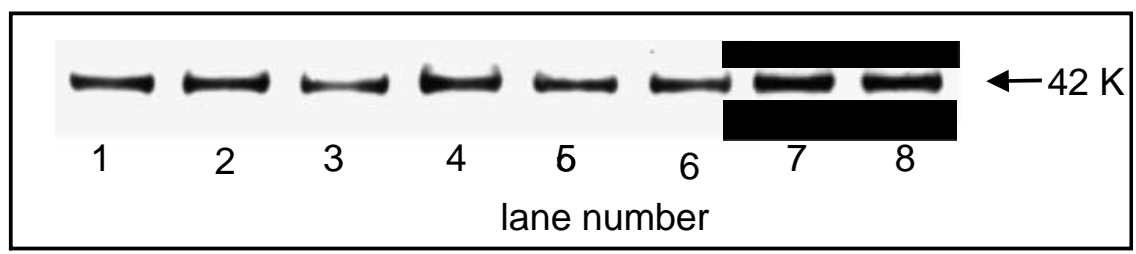

C

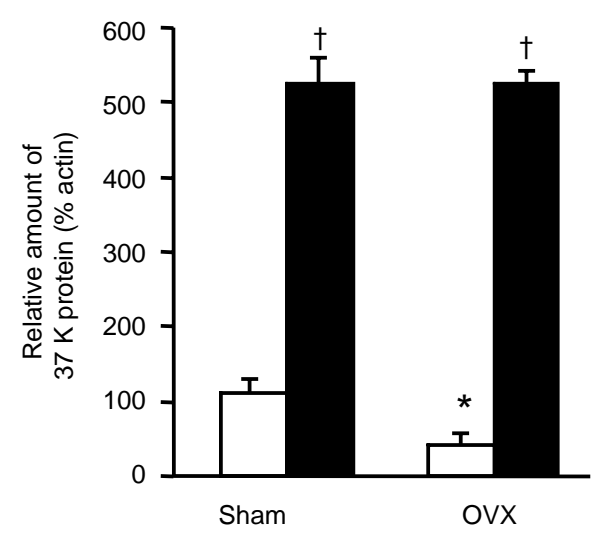

$\mathrm{D}$



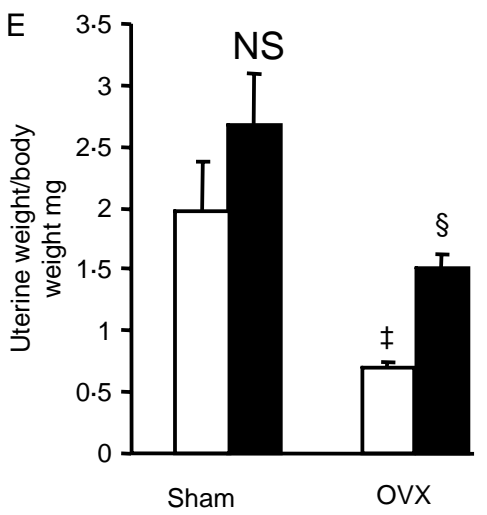

Figure 1 Western blots showing the effect of ovariectomy and replacement $17 \beta$-estradiol $\left(E_{2}\right)$ treatment for $24 \mathrm{~h}$ on pituitary ANXA1 content; (A) shows ANXA1, (B) shows $\beta$-actin loading control. Vehicletreated OVX, lanes 1 and 2; vehicle-treated sham-operated, lanes 3 and 4; $E_{2}$-treated OVX, lanes 5 and 6 ; $\mathrm{E}_{2}$-treated sham-operated, lanes 7 and 8. (C) Histogram showing integrated densitometry data; open columns, vehicle-treated; and filled columns, $\mathrm{E}_{2}$-treated. Values are expressed as means \pm s.E.M., $n=6$ animals. ${ }^{*} P<0 \cdot 01$ versus sham-operated; ${ }^{\dagger} P<0 \cdot 01$ versus respective vehicle-treated, ANOVA. (D and E) The effect of ovariectomy and replacement with $E_{2}$ for $24 \mathrm{~h}$ on (D) serum corticosterone and (E) uterine weights in female rats. Open columns, vehicle-treated; filled columns, $E_{2}$-treated. Values are expressed as means \pm S.E.M., $n=6$ animals. ${ }^{\ddagger} P<0.05$ versus sham vehicle; ${ }^{\circledR} P<0.01$ versus OVX vehicle; NS, not significant versus sham vehicle; ANOVA plus Scheffe's test. 

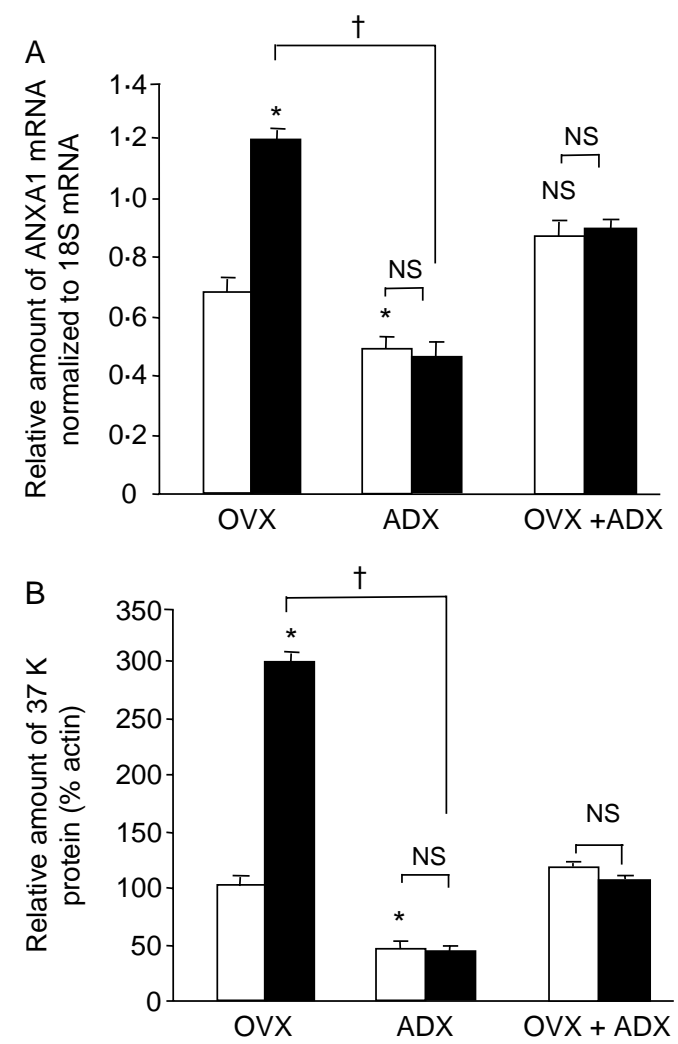

C

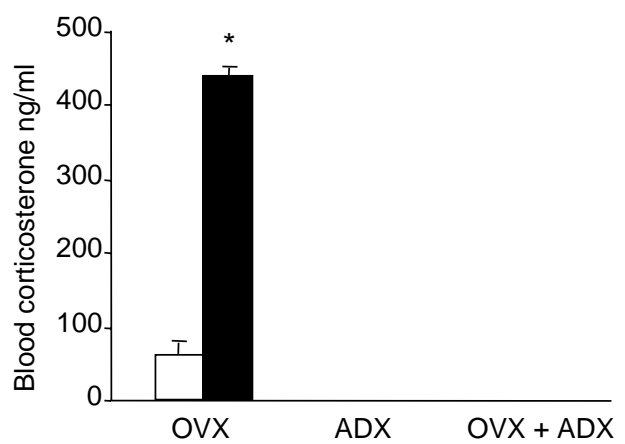

Figure 2 Histograms illustrating the effect of OVX, ADX, and OVX/ADX and $17 \beta$-estradiol treatment in female rats on $(A)$ anterior pituitary ANXA1 mRNA, measured by real-time PCR, (B) anterior pituitary ANXA1 protein, measured by western blot analysis, and (C) blood corticosterone. Open columns, vehicle-treated; filled columns, $17 \beta$-estradiol-treated. Values are expressed as means \pm S.E.M., $n=6$ animals. NS, not significant versus corresponding vehicle control; ${ }^{*} P<0 \cdot 05$ versus vehicle-treated $\mathrm{OVX},{ }^{\dagger} P<0 \cdot 05$ versus $17 \beta$-estradiol-treated OVX; ANOVA plus Scheffe's test.

resulted in a significant decrease $(P<0 \cdot 05)$ in anterior pituitary ANXA1 mRNA (Fig. 2A) and protein (Fig. 2B) compared with OVX. Administration of $17 \beta$-estradiol to ADX and ADX/OVX females did not alter the expression of ANXA1 mRNA or protein (Fig. 2A and B). Measurement of corticosterone (Fig. 2C) demonstrated that concentrations were significantly $(P<0 \cdot 05)$ elevated in $17 \beta$-estradiol-treated OVX animals compared with vehicle-treated OVX and confirmed the effectiveness of ADX.

\section{Western blot analysis of ANXA1 expression during the estrous cycle}

ANXA1 was measured by western blot analysis in anterior pituitary glands from female rats in each estrous cycle stage in order to investigate alterations in ANXA1 protein content in the estrous cycle. Figure 3 illustrates the effect of the estrous cycle on anterior pituitary ANXA1 content. Typical western blots are shown in Fig. 3A-D and densitometry data in Fig. 3E-F. The amount of ANXA1 in anterior pituitary (Fig. $3 \mathrm{~A}$ and $\mathrm{E}$ ) began to reduce at metestrus $>$ diestrus and was significantly reduced by approximately a fivefold reduction at proestrus $(P<0.01$ versus estrus; Fig. 3A proestrus lanes 7 and 8 versus estrus lanes 1 and 2). However, no change was observed in the amount of $\beta$-actin detected (Fig. 3B). The ANXA1 content of male anterior pituitary was intermediate to that of proestrus and estrus females (Fig. 3C and $\mathrm{E})$ and no difference was observed in $\beta$-actin levels (Fig.3D). Measurement of corticosterone demonstrated highest circulating concentrations at proestrus and lowest concentrations at estrus as previously reported (Fig. 3F; Carey et al. 1995).

\section{Regulation of ANXA1 by 17 $\beta$-estradiol in TtT/GF cells}

In order to explore the possibility of direct actions of $17 \beta-$ estradiol on ANXA1 expression in FS cells, the effects of graded concentrations of $17 \beta$-estradiol $(0 \cdot 18-1800 \mathrm{nM})$ on ANXA1 mRNA and protein content in the TtT/GF FS cell line were investigated. Initial immunofluorescence microscopy studies localized the subcellular distribution of $\mathrm{ER} \alpha$ and ER $\beta$ in TtT/GF cells (Fig. 4). In control- and $17 \beta$-estradiol-treated $(24 \mathrm{~h}, 180 \mathrm{nM})$ conditions, strong immunofluorescent staining for ER $\alpha$ (Fig. $4 \mathrm{~A}-\mathrm{F}$ ) and ER $\beta$ (Fig. 4G-L) was localized to the nucleus with weaker immunofluorescence extended throughout the cytoplasm. No non-specific immunolabeling was detected in absorbed antibody controls (Fig. 4M and N). The effects of incubating $\mathrm{TtT} / \mathrm{GF}$ cells for $24 \mathrm{~h}$ with increasing concentrations of $17 \beta$-estradiol $(0 \cdot 18-1800 \mathrm{nM})$ on the amount of ANXA1 mRNA and protein are shown in Fig. 5. Real-time PCR assay of ANXA1 mRNA in TtT/GF cells confirmed that the positive control stimulus dexamethasone $(0 \cdot 1 \mu \mathrm{M}, 24 \mathrm{~h})$ produced a significant $(P<0.05)$ increase in ANXA1 mRNA and revealed that $17 \beta$-estradiol $(1 \cdot 8-180 \mathrm{nM}, 24 \mathrm{~h})$ caused a concentration-dependent increase in ANXA1 mRNA (Fig. 5A). In contrast, western blot analysis demonstrated no significant effect of graded concentrations of $17 \beta$-estradiol (0·18-1800 nM, 24 h; Fig. 5B and C) and no significant effect of $17 \beta$-estradiol $(18 \mathrm{nM})$ treatment for various periods ( $0-24 \mathrm{~h}$; Fig. $5 \mathrm{D})$ on ANXA1 protein content in $\mathrm{TtT} / \mathrm{GF}$ cells. However, pretreatment of $\mathrm{TtT} / \mathrm{GF}$ cells 


\section{A}

ANXA1
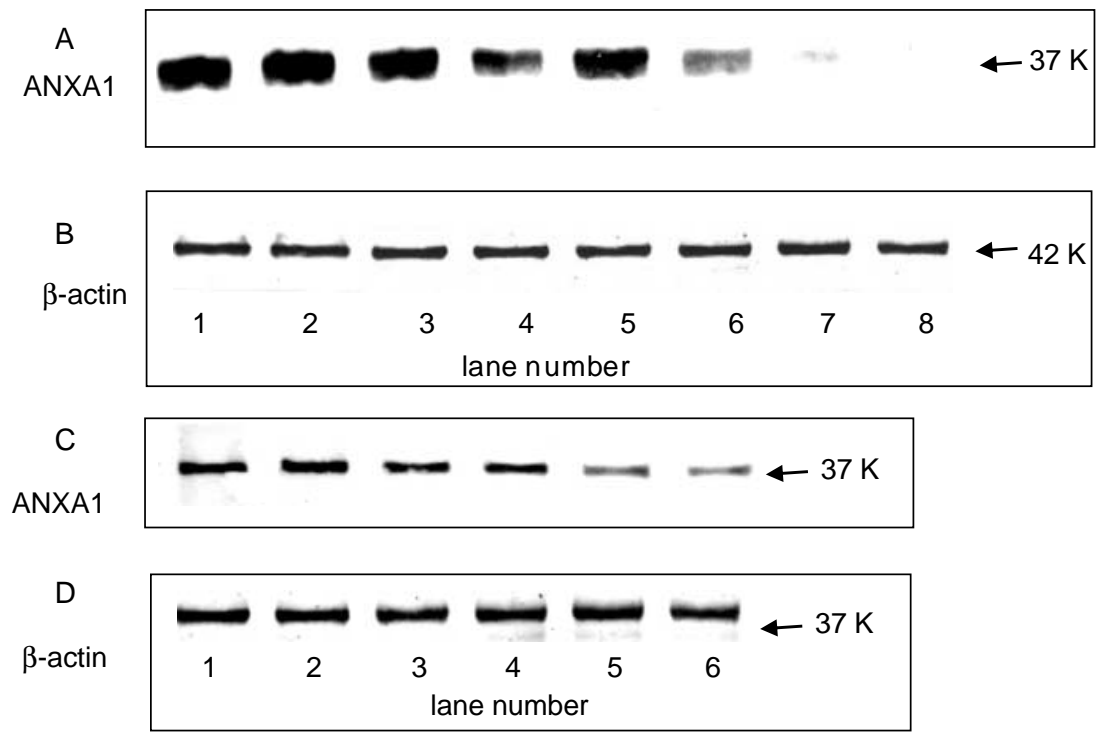

E

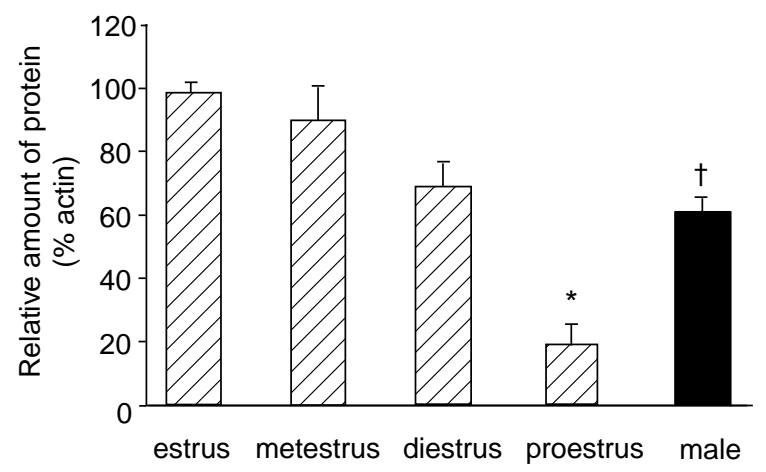

$\mathrm{F}$

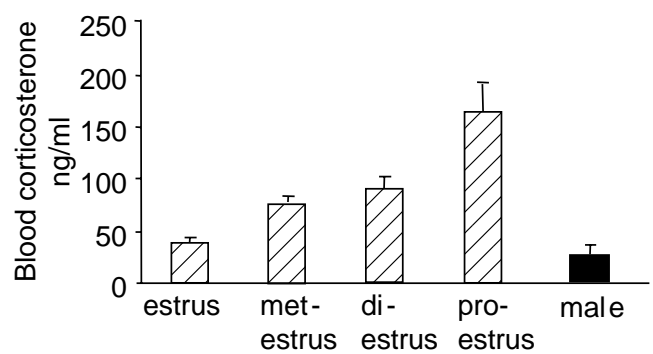

Figure 3 Western blots showing anterior pituitary ANXA1 tissue content at estrus, metestrus, diestrus, and proestrus in female rats; (A) shows ANXA1, (B) shows $\beta$-actin. Estrus, lanes 1 and 2; metestrus, lanes 3 and 4; diestrus, lanes 5 and 6; proestrus, lanes 7 and 8. (C) and (D) Comparison of anterior pituitary (C) ANXA1 tissue content and (D) $\beta$-actin control in male rats and proestrus and estrus female rats. Estrus, lanes 1 and 2; males, lanes 3 and 4; proestrus, lanes 5 and 6 . Histograms showing (E) integrated densitometry data and (F) blood corticosterone measured at estrus, metestrus, diestrus, and proestrus in female rats, and in male rats. Values are expressed as means \pm s.E.M., $n=6$ animals. ${ }^{*} P<0 \cdot 01,{ }^{\dagger} P<0 \cdot 05$ versus estrus; ANOVA plus Scheffe's test. 

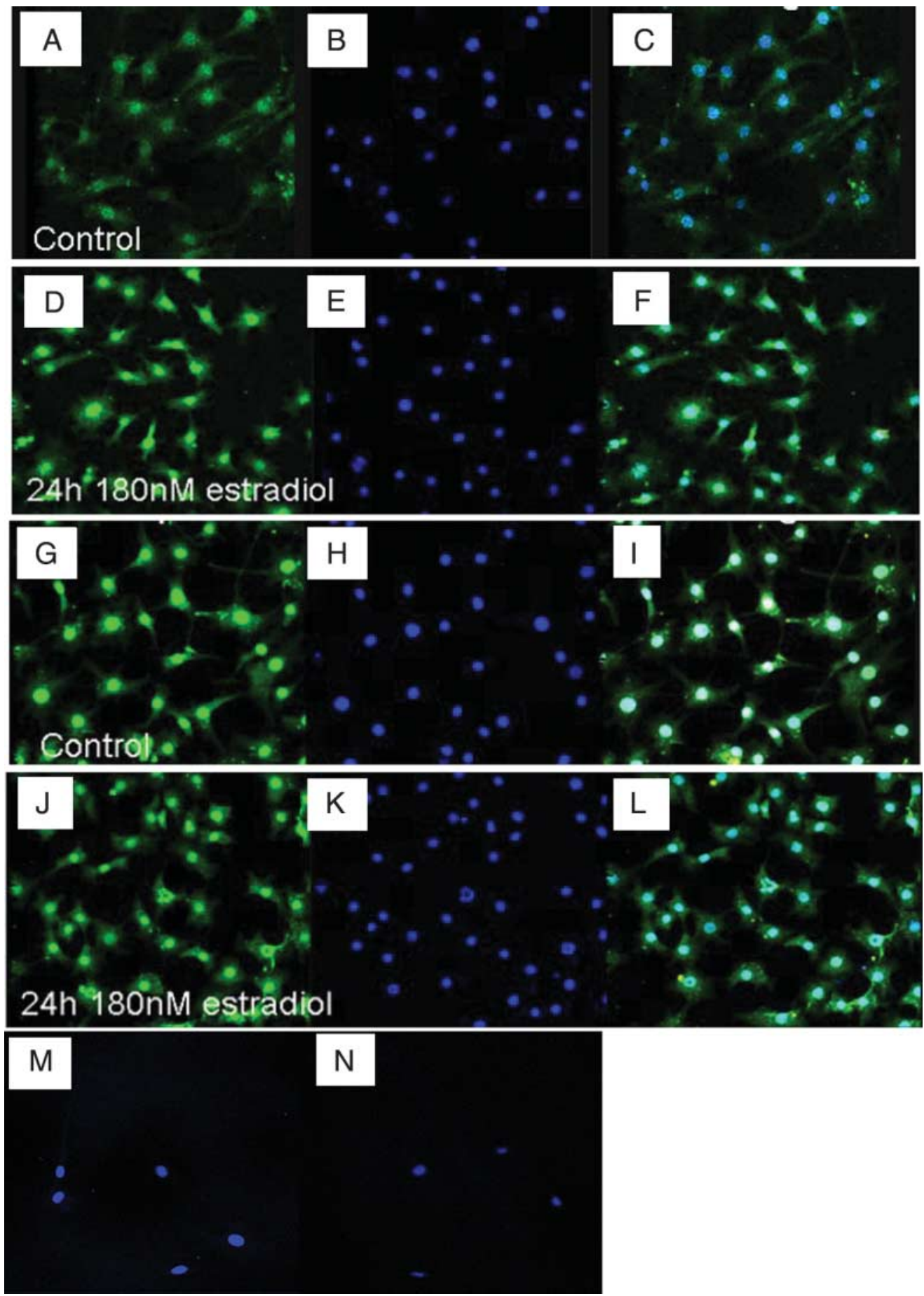

Figure 4 Localization of $E R \alpha(A-F)$ and $E R \beta(G-L)$ receptors in control- and $17 \beta$-estradiol $\left(E_{2} ; 180 \mathrm{nM}, 24 \mathrm{~h}\right)$ treated TtT/GF cells by immunofluorescence microscopy. Figures show fluorescence images of labeling of: $\mathrm{A}$ and $\mathrm{D}, \mathrm{ER} \alpha ; \mathrm{G}$ and J, ER $\beta ; \mathrm{B}, \mathrm{E}, \mathrm{H}$ and $\mathrm{K}, \mathrm{TO}-\mathrm{PRO} 3$ nuclear counterstain; $\mathrm{C}, \mathrm{F}, \mathrm{I}, \mathrm{L}$ overlay of corresponding ER and nuclear counterstain images. ER $\alpha$, control (A-C), $E_{2}$-treated (D-F); $E R \beta$, control $(G-I), E_{2}$-treated (J-L). (M) ER $\alpha$ preabsorbed antibody negative control, (N) ER $\beta$ preabsorbed antibody negative control. Magnification, $\times 250$. 
A

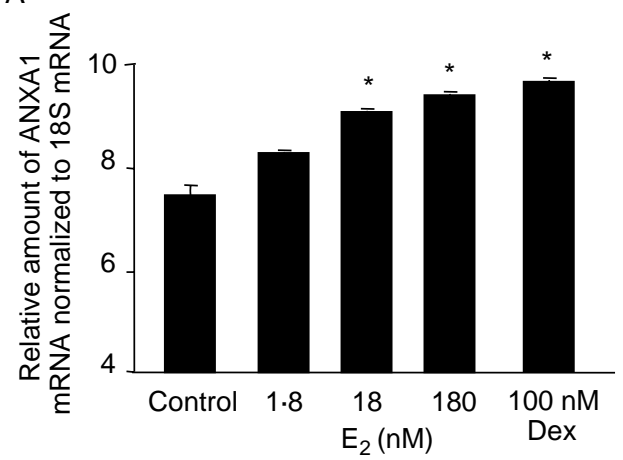

B

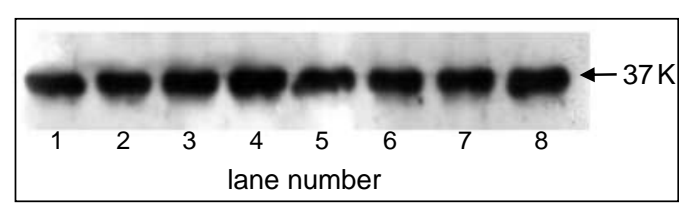

C



D

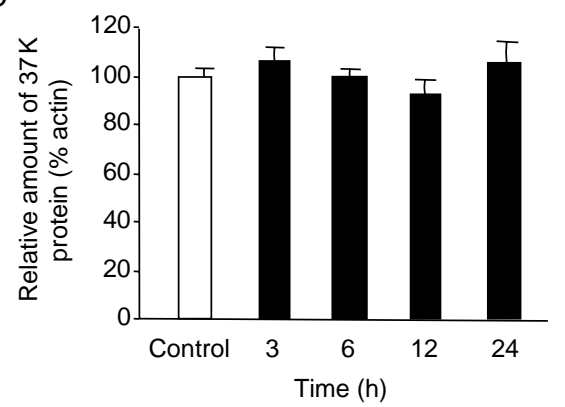

Figure 5 (A) Effect of $17 \beta$-estradiol $\left(E_{2} ; 1 \cdot 8-180 \mathrm{nM}, 24 \mathrm{~h}\right)$ and dexamethasone (Dex; $0 \cdot 1 \mu \mathrm{M}, 24 \mathrm{~h}$ ) on the amount of ANXA1 mRNA in TtT/GF cells measured by quantitative PCR. Values expressed as means \pm S.E.M., $n=3$ experiments $* P<0 \cdot 01$ versus negative control, ANOVA. (B) Effect of $E_{2}(1 \cdot 8-180 \mathrm{nM}, 24 \mathrm{~h})$ on the amount of ANXA1 protein in TtT/GF cells. Western blot: lanes 1 and 2, control; lanes 3 and 4, 1.8 $\mathrm{nM} \mathrm{E}_{2}$-treated; lanes 5 and 6, $18 \mathrm{nM}$ $\mathrm{E}_{2}$-treated; lanes 7 and 8, $180 \mathrm{nM} \mathrm{E}_{2}$-treated. (C) and (D) Integrated densitometry data of the effects of $(\mathrm{C})$ increasing concentrations of $\mathrm{E}_{2}(0 \cdot 18-1800 \mathrm{nM}, 24 \mathrm{~h})$ and (D) duration of treatment with $18 \mathrm{nM}$ $\mathrm{E}_{2}(3-24 \mathrm{~h})$ on the amount of ANXA1 in TtT/GF cells. Open columns, vehicle control; filled columns, $17 \beta$-estradiol-treated. Values expressed as means \pm s.E.M., $n=3$ experiments; no significant differences measured versus control, ANOVA. with $17 \beta$-estradiol $(100 \mathrm{nM}, 24 \mathrm{~h})$ significantly $(P<0 \cdot 05)$ increased the amount of surface ANXA1 detected in response to dexamethasone-stimulated $(0 \cdot 1 \mu \mathrm{M}, 3 \mathrm{~h})$ externalization (Fig. 6A, lanes 7 and $817 \beta$-estradiol and dexamethasonetreated versus lanes 3 and 4 control- and dexamethasonetreated; Fig. 6D), whereas the amount of intracellular ANXA1 measured was unaffected (Fig. 6C and E). No actin ir bands were detected in cell surface EDTA washes (Fig. 6B) confirming cell integrity. In subsequent experiments, the effect of co-treatment of $\mathrm{TtT} / \mathrm{GF}$ cells with $17 \beta$-estradiol $(18 \mathrm{nM})$ and dexamethasone $(0 \cdot 1 \mu \mathrm{M})$ for $24 \mathrm{~h}$ on ANXA1 content was measured (Fig. 7). Western blot analysis confirmed that dexamethasone alone significantly $(P<0.05)$ increased ANXA1 content, whereas $17 \beta$-estradiol treatment $(18 \mathrm{nM})$ alone had no significant effect (Fig. 7A, lanes 1 and 2 control versus lanes 3 and 4 dexamethasonetreated versus lanes 5 and $617 \beta$-estradiol-treated). However, co-treatment of TtT/GF cells with $17 \beta$-estradiol $(18 \mathrm{nM})$ and dexamethasone $(0 \cdot 1 \mu \mathrm{M})$ for $24 \mathrm{~h}$ significantly $(P<0 \cdot 05)$ enhanced ANXA1 content compared with dexamethasone treatment alone (Fig. 7A, lanes 7 and 8 dexamethasone and $17 \beta$-estradiol-treated versus lanes 3 and 4 dexamethasone alone). However, no change was observed in the amount of $\beta$-actin detected (Fig. 7B).

\section{Dexamethasone inhibition of basal- and CRH-stimulated ACTH release from pituitary segments in vitro}

ANXA1 mediates certain acute inhibitory actions of the glucocorticoids on ACTH release (Taylor et al. 1997). As significant differences in ANXA1 anterior pituitary content were measured after $17 \beta$-estradiol treatment compared with OVX, and in proestrus compared with estrus, we compared the inhibitory effects of dexamethasone in vitro on basal and stimulated ACTH release in these groups. The inhibitory effects of dexamethasone $(0 \cdot 1 \mu \mathrm{M})$ on the release of ir-ACTH induced by $\mathrm{CRH}(10 \mathrm{nM})$ from OVX- and $17 \beta$-estradioltreated OVX female pituitary segments in vitro is demonstrated in Fig. 8A. No significant difference in the basal release of ir-ACTH or the significant $(P<0 \cdot 01)$ increases in peptide release induced by CRH were detected between OVX- and $17 \beta$-estradiol-treated OVX groups. However, a significantly greater inhibition $(P<0 \cdot 05)$ by dexamethasone of $\mathrm{CRH}-$ stimulated ir-ACTH release was measured in OVX pituitary segments compared with $17 \beta$-estradiol-treated OVX segments (Fig. 8A). Figure $8 \mathrm{~B}$ similarly compares the inhibitory effects of dexamethasone $(0 \cdot 1 \mu \mathrm{M})$ on the release of ir-ACTH induced by $\mathrm{CRH}(10 \mathrm{nM})$ from anterior pituitary segments from proestrus and estrus female rats. No significant difference in the basal release of ir-ACTH or the significant $(P<0 \cdot 01)$ increases in peptide release induced by $\mathrm{CRH}$ were detected between proestrus and estrus pituitary segments. However, a significantly greater inhibition $(P<0 \cdot 05)$ by dexamethasone of $\mathrm{CRH}$-stimulated ir-ACTH release was measured in proestrus compared with estrus segments (Fig. 8B). 

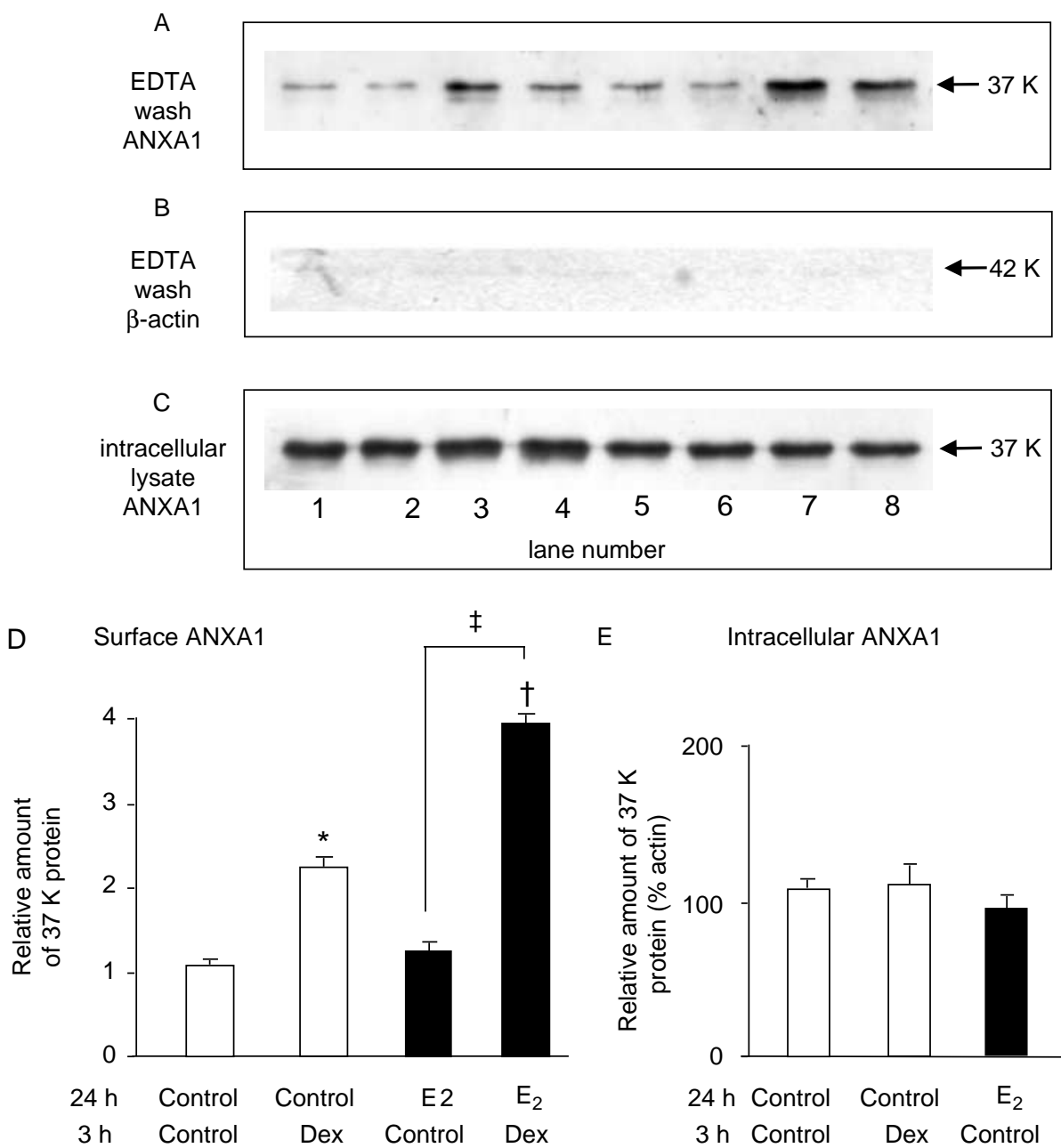

E Intracellular ANXA1

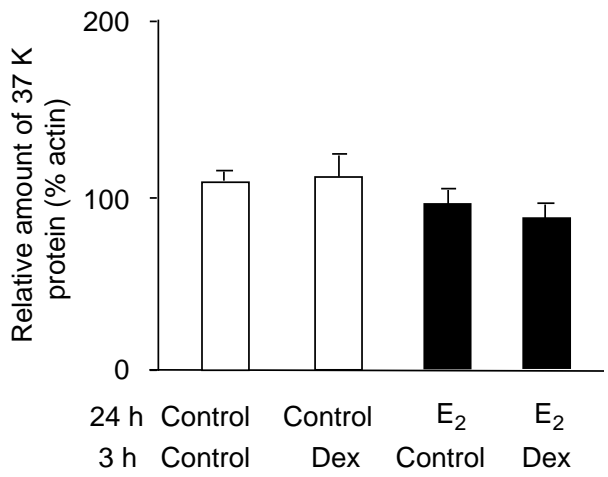

Figure 6 Effect of $17 \beta$-estradiol $\left(E_{2}\right)$ on $(A)$ the amount of ANXA1 in the EDTA wash, i.e. cell surface ANXA1, (B) $\beta$-actin in the EDTA wash (negative control), and (C) intracellular ANXA1 in control and dexamethasone (Dex)stimulated $(0 \cdot 1 \mu \mathrm{M}, 3 \mathrm{~h}) \mathrm{TtT} / \mathrm{GF}$ cells. ANXA1 and $\beta$-actin were measured by western blot analysis. Western blots: control, lanes 1 and 2; vehicle (24 h) plus Dex-treated $(0 \cdot 1 \mu \mathrm{M}, 3 \mathrm{~h})$, lanes 3 and 4; $\mathrm{E}_{2}$-treated (180 nM, $\left.24 \mathrm{~h}\right)$ plus vehicle ( $3 \mathrm{~h}$ ), lanes 5 and 6; $E_{2}$ plus Dex-treated, lanes 7 and 8 . (D) Integrated densitometry data for surface ANXA1 measured. (E) Integrated densitometry data for intracellular ANXA1 measured. Open columns, vehicle control; filled columns, $17 \beta$-estradiol-treated; treatment group is shown below the columns. Values expressed as means \pm S.E.M., $n=3$ experiments; ${ }^{*} P<0 \cdot 05,{ }^{\dagger} P<0 \cdot 01$ versus negative control; ${ }^{\ddagger} P<0 \cdot 05$ versus corresponding $\mathrm{E}_{2}$-free control, ANOVA.

\section{Discussion}

To test the hypothesis that $17 \beta$-estradiol regulates ANXA1 expression, we measured pituitary ANXA1 content following ovariectomy and $17 \beta$-estradiol replacement in rats. OVX- and sham-operated rats were treated with a concentration of $17 \beta$-estradiol previously shown to mimic physiological levels (Young et al. 2001). The uterine weight in $17 \beta$-estradioltreated OVX rats was not significantly different to shamoperated rats suggesting that normal circulating concentrations of the hormone were restored. In OVX rats, the anterior pituitary content of ANXA1 was significantly reduced compared with sham-operated controls and in both the sham-operated and OVX animals $17 \beta$-estradiol replacement caused a significant increase in anterior pituitary ANXA1 content. Pituitary ANXA1 is expressed strongly in FS cells (Traverso et al. 1999) and to date, glucocorticoids are the principal factors known to stimulate ANXA1 synthesis in FS cells (Ozawa et al. 2002, John et al. 2004). The potent effects of ovariectomy on HPA axis activity have been well documented (Burgess \& Handa 1992, Carey et al. 1995, Seale et al. 2004) and consistent with these studies we found that ovariectomy produced a significant decrease in blood corticosterone that was reversed by administration of $17 \beta$-estradiol. $17 \beta$-Estradiol 
A Total cellular ANXA1

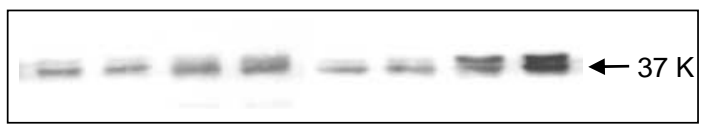

B $\quad \beta$ actin loading control
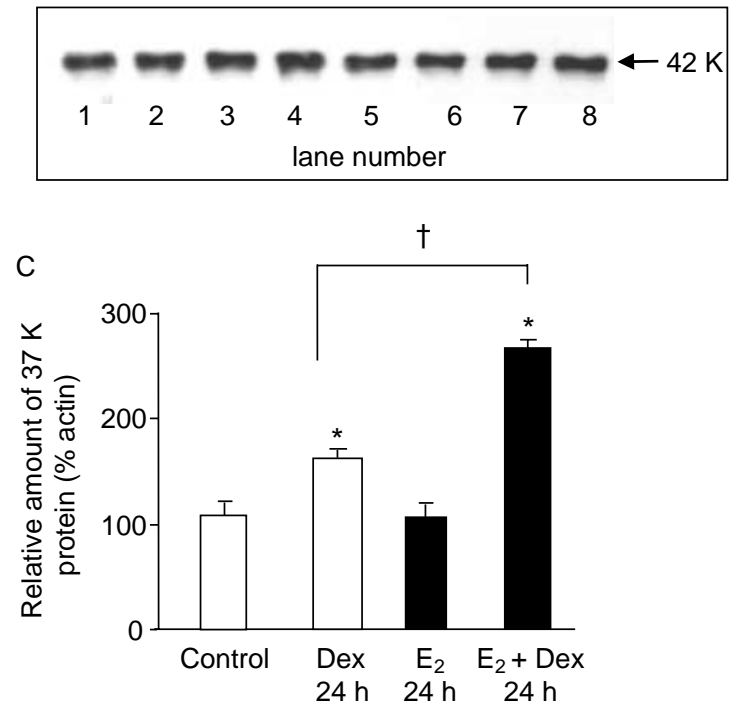

Figure 7 Effect of $17 \beta$-estradiol $\left(E_{2} ; 18 \mathrm{nM}, 24 \mathrm{~h}\right)$ and dexamethasone (Dex; $0 \cdot 1 \mu \mathrm{M}, 24 \mathrm{~h}$ ) on the amount of total ANXA1 protein in TtT/GF cells. Western blots showing (A) ANXA1, (B) $\beta$-actin, loading control: lanes 1 and 2, control; lanes 3 and 4 ,

dexamethasone-treated; lanes 5 and 6, $\mathrm{E}_{2}$-treated; lanes 7 and 8 co-treated with Dex and $E_{2}$. (C) Integrated densitometry data. Open columns, vehicle control; filled columns, $17 \beta$-estradiol-treated; treatment group is shown below the columns. Values expressed as means \pm S.E.M., $n=3$ experiments; ${ }^{*} P<0 \cdot 05$, versus corresponding Dex-free control; ${ }^{\dagger} P<0.05$ versus corresponding $\mathrm{E}_{2}$-free control, ANOVA.

has been shown to stimulate adrenal corticosterone release both directly and via modulation of glucocorticoid feedback mechanisms (Peiffer \& Barden 1987, Peiffer et al. 1991, Burgess \& Handa 1992, Redei et al. 1994, Lo et al. 2000). It was therefore possible that $17 \beta$-estradiol treatment increased the amount of anterior pituitary ANXA1 expression via changes in circulating glucocorticoid concentrations secondary to estradiol treatment and/or via a direct pituitary action on FS cells.

In order to test whether the $17 \beta$-estradiol-induced increase in anterior pituitary ANXA1 content in vivo may be via increased corticosterone release from the adrenal gland, $17 \beta$ estradiol was administered to ADX and combined OVX/ADX animals, and ANXA1 mRNA and protein measured. $17 \beta$-Estradiol significantly increased anterior pituitary ANXA1 mRNA and protein content in the OVX rats relative to vehicle OVX controls but no such increase in response to $17 \beta$-estradiol was observed in the ADX or double OVX/ADX groups. These findings show that in the absence of the adrenal gland and circulating corticosterone,
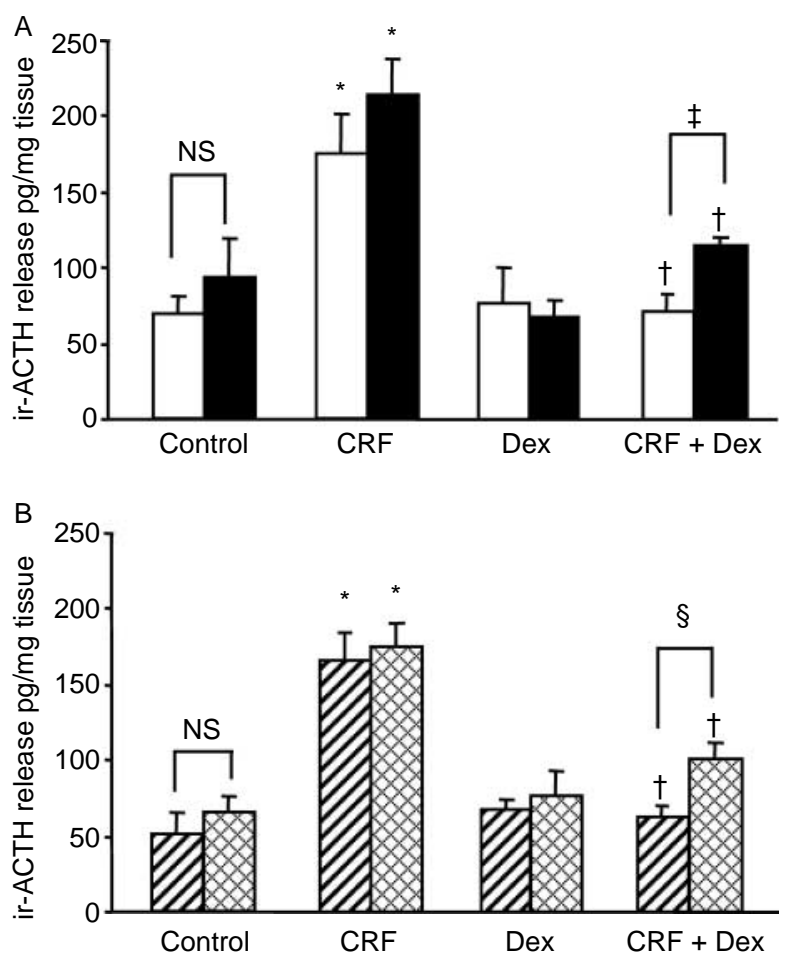

Figure 8 The inhibitory effects of dexamethasone $(0 \cdot 1 \mu \mathrm{M})$ on the release of ir- $\mathrm{ACTH}$ induced by $\mathrm{CRH}(10 \mathrm{nM})$ from $(\mathrm{A})$ vehicle versus $17 \beta$-estradiol $\left(E_{2}\right)$-treated anterior pituitary segments from OVX rats in vitro; open columns, vehicle; filled columns, $\mathrm{E}_{2}$-treated; and (B) anterior pituitary tissue from proestrus and estrus females; hashed columns, proestrus, crossed pattern columns, estrus. Values are expressed as means \pm S.E.M., $n=6$. ${ }^{*} P<0.05$ versus corresponding control. ${ }^{\dagger} P<0 \cdot 05$ versus corresponding dexamethasone-free control. ${ }^{\ddagger} P<0.05$ OVX versus OVX $E_{2} 24 \mathrm{~h} ;{ }^{\S} P<0.05$ proestrus versus estrus, ANOVA plus Scheffe's test.

$17 \beta$-estradiol was unable to induce an increase in anterior pituitary ANXA1 expression. An unexpected observation was that combined ADX and OVX produced an increase in ANXA1 expression, greater than in the adrenalectomy alone groups. The ability of OVX to partially reduce the effects of ADX on ANXA1 expression implies that gonadal steroids may have inhibitory as well as permissive actions. It is therefore possible that progesterone could also play a role in the regulation of ANXA1 expression opposing the actions of estrogen, which we are currently investigating.

Western blot analysis revealed that anterior pituitary ANXA1 content varied with the estrous cycle. ANXA1 content was robustly decreased during proestrus and increased in estrus. Estradiol concentrations vary with the rat estrous cycle, being low at estrus, beginning to increase at late metestrus, reaching a sharp peak at early afternoon of proestrus from which levels start to decline by early evening of proestrus. Corticosterone blood concentrations also vary with the estrous cycle such that levels are highest in the afternoon of proestrus (Carey et al. 1995), coinciding with the time of maximal $17 \beta$-Estradiol secretion. One possible 
explanation is that the change in ANXA1 is due to the surge in estradiol during proestrus, and mediated via changes in plasma corticosterone. However, it could also be that the combination of estradiol and progesterone in proestrus drives ANXA1 synthesis down and that the presence of estradiol in the absence of progesterone during estrus increases ANXA1 synthesis. The ability of OVX to partially reduce the effects of ADX on ANXA1 expression supports the hypothesis that gonadal steroids also have inhibitory actions. Although estrogen treatment in male rats has been shown to either induce (48 h treatment; Feldman et al. 1979) or reduce $(72 \mathrm{~h}$ treatment; Smith \& Hammond 1992) corticosterone binding globulin $(\mathrm{CBG})$ production and secretion, $\mathrm{CBG}$ concentrations remain unchanged in estrogen-treated intact or OVX female rats (up to 10 days treatment tested; Gala \& Westphal 1965, 1966). Therefore, in the present study, it is unlikely that 24- $\mathrm{h}$ estrogen treatment induced changes in $\mathrm{CBG}$ that contributed to the effects observed.

Although the promoter region of the ANXA1 gene lacks a classical estrogen response element sequence, it does contain a cAMP-responsive element through which dexamethasone and estradiol have been shown to induce ANXA1 transcription (Wallner et al. 1986, Horlick et al. 1991). Studies in a human CCRF-CEM acute lymphoblastic leukemia cell line have demonstrated that $17 \beta$-estradiol (at $1 \mu \mathrm{M}$ ) increases ANXA1 mRNA synthesis and cell surface ANXA1 (Castro-Caldas et al. 2001) by a mechanism requiring AMP response element (CRE)-binding protein (Castro-Caldas et al. 2003). We therefore investigated the possibility of direct effects of $17 \beta$-estradiol on ANXA1 expression in a FS cell line. The TtT/GF cell line is a well-characterized pituitary FS cell line, which closely models pituitary FS cells (Chapman et al. 2003, Tierney et al. 2003, Omer et al. 2006). FS cells express intracellular estrogen receptors (Mitchner et al. 1998) and RT-PCR analysis has demonstrated the expression of ER $\alpha$ and ER $\beta$ mRNA in TtT/GF cells (Nagashima et al. 2003). By immunofluorescence methods, we localized the subcellular distribution of $\mathrm{ER} \alpha$ and $\mathrm{ER} \beta$ in TtT/GF cells and revealed that in control- and $17 \beta$-estradiol-treated conditions, $\operatorname{ER} \alpha$ and $\operatorname{ER} \beta$ were localized predominantly in the nucleus, consistent with previous receptor localization studies in gonadotropes (Sanchez-Criado et al. 2005). Treatment of TtT/GF cells with $17 \beta$-estradiol stimulated an increase in ANXA1 mRNA as measured by QPCR. No significant change in the amount of ANXA1 protein was measured in response to the range of concentrations of $17 \beta$-estradiol tested. However, the trend for estradiol regulation of ANXA1 protein expression was upward and it is not unusual for protein changes to be smaller than mRNA changes as mRNA and protein stoichiometry is not 1:1. It is well established that glucocorticoids induce the expression and externalization of ANXA1 in TtT/GF cells (Chapman et al. 2002, Omer et al. 2006). Pretreatment of TtT/GF cells with $17 \beta$-estradiol for $24 \mathrm{~h}$ increased the amount of ANXA1 synthesized and externalized in response to a subsequent dexamethasone stimulus compared with untreated controls. Furthermore, co-treatment of cells with $17 \beta$-estradiol and dexamethasone for $24 \mathrm{~h}$ enhanced pituitary ANXA1 protein content compared with the response to dexamethasone alone. Together, these results in a FS cell line suggest that $17 \beta-$ estradiol acts to enhance the production of ANXA1 mRNA and release of ANXA1 in response to glucocorticoid. However, in vivo $17 \beta$-estradiol did not influence ANXA1 mRNA or protein expression in ADX rats suggesting that either $17 \beta$-estradiol does not have a direct effect in the rat pituitary or the effect is inhibited by an unknown factor in ADX conditions.

In the male anterior pituitary, ANXA1 plays a key role in the manifestation of the early delayed feedback effects of glucocorticoids (reviewed in John et al. 2004). We compared the suppression of CRH-stimulated ACTH release by dexamethasone in proestrus pituitary compared with estrus and in OVX compared with estradiol-treated OVX tissue. Suppression of CRH-stimulated ACTH release by dexamethasone produced significantly greater inhibition in proestrus pituitary compared with estrus and in OVX compared with estradiol-treated OVX tissue. Therefore, in conditions of greater pituitary ANXA1 expression and greater estradiol exposure, the degree of glucocorticoid suppression of ACTH release in vitro was less. These data suggest that there is not a direct correlation between the concentration of ANXA1 in the pituitary and the glucocorticoid feedback inhibition. However, the ANXA1 antibody used in these studies does not discriminate between the different phosphorylation states of ANXA1 and it may be that the phosphorylation (or other modification) of ANXA1 is a more important indicator of the functional action of ANXA1 than the total quantity (Solito et al. 2006). Conversely, in the female ANXA1 null mouse, basal HPA parameters were not altered compared with wild type, whereas in male ANXA1 null mice anterior pituitary corticotrope number and ACTH content were increased suggesting there may be a less critical role for ANXA1 in females (Morris et al. 2006).

Sexual dimorphism in the immune and inflammatory response in humans is well known. Females produce more vigorous cellular and humoral reactions, are more resistant to certain infections, and suffer a higher incidence of autoimmune diseases (e.g. rheumatoid arthritis) than males (Bouman et al. 2005). Disease expression is also influenced by the reproductive status of the female. In ANXA1 null mice, the male ANXA1 null leukocyte response to experimental inflammation was enhanced to a greater extent than the female response (Hannon et al. 2003). Our findings demonstrating gender differences in ANXA1 expression may therefore contribute to the gender differences underlying susceptibility to autoimmune and inflammatory diseases.

In summary, $17 \beta$-estradiol treatment in vivo increased ANXA1 expression in the anterior pituitary by a mechanism that involves the adrenal gland. The parallel changes in ANXA1 expression and in circulating corticosterone in response to $17 \beta$-estradiol, suggest it is possible that 
corticosterone has a role in the mechanism of action of $17 \beta$ estradiol. Further studies investigating the effects of a glucocorticoid receptor antagonist, such as RU486, are required to verify this possibility. The exact cell targets of $17 \beta$-estradiol action in vivo that lead to upregulation of ANXA1 are unknown but could include indirect regulation of brain, pituitary, and/or adrenal receptors or secretagogs that influence corticosterone release or via a direct adrenal action (Peiffer \& Barden 1987, Peiffer et al. 1991, Burgess \& Handa 1992, Lo et al. 2000). Experiments in TtT/GF cells indicate a direct action of $17 \beta$-estradiol to enhance ANXA1 mRNA content and externalization in response to glucocorticoid. Together, these data are consistent with the hypothesis that estrogens contribute to the regulation of pituitary ANXA1 expression and suggest that changes in ANXA1 may relate to known gender differences in stress responsivity and susceptibility to autoimmune and inflammatory diseases.

\section{Acknowledgements}

We thank Lynne Scott and Sarah Rodgers for expert technical support.

\section{Funding}

This work was supported by the Wellcome Trust and there is no conflict of interest that would prejudice its impartiality.

\section{References}

Bouman A, Heineman MJ \& Faas MM 2005 Sex hormones and the immune response in humans. Human Reproduction Update 11 411-423.

Burgess LH \& Handa RJ 1992 Chronic-estrogen induced alterations in adrenocorticotrophin and corticosterone secretion and glucocorticoid receptor mediated functions on female rats. Endocrinology 131 $1261-1269$.

Carey MP, Deterd CH, deKoning J, Helmerhorst F \& deKloet ER 1995 The influence of ovarian steroids on hypothalamic-pituitary-adrenal regulation in the female rat. Journal of Endocrinology 144 311-321.

Castro-Caldas M, Duarte CB, Carvalho AP \& Lopes MCF 2001 Estradiol promotes the synthesis and the secretion of annexin 1 in the CCRF-CEM human cell line. Mediators of Inflammation 10 245-251.

Castro-Caldas M, Mendes AF, Duarte CB \& Lopes MCF 2003 Dexamethasone-induced and estradiol-induced CREB activation and annexin 1 expression in CCRF-CEM lymphoblastic cells:evidence for the involvement of cAMP and p38 MAPK. Mediators of Inflammation 12 329-337.

Chapman LP, Nishimura A, Buckingham JC, Flower RJ, Morris JF \& Christian HC 2002 Externalisation of annexin I from a folliculo-stellate, TtT/GF, cell line. Endocrinology 143 4330-4338.

Chapman LP, Epton MJ, Buckingham JC, Flower RJ, Morris JF \& Christian HC 2003 Evidence for a role of the ATP-binding cassette transporter A1 (ABCA1) in the externalisation of annexin 1 from pituitary folliculostellate cells. Endocrinology 144 1062-1073.

Christian HC, Taylor AD, Flower RJ, Morris JF \& Buckingham JC 1997 Characterization and localization of lipocortin 1-binding sites on rat anterior pituitary cells by fluorescence-activated cell analysis/sorting and electron microscopy. Endocrinology 138 5341-5351.
Critchlow V, Liebelt RA, Bar-Sela M, Mountcastle W \& Lipscomb HS 1963 Sex difference in resting pituitary-adrenal function in the rat. American Journal of Physiology 205 807-815.

Feldman D, Mondon CE, Horner JA \& Weiser JN 1979 Glucocorticoid and estrogen regulation of corticosteroid binding globulin production by the liver. American Journal of Physiology 237 E493-E499.

Freeman M 1994 The neuroendocrine control of the ovarian cycle of the rat. In The Physiology of Reproduction, edn 2, pp 111-149. Eds E Knobil \& JD Neill. New York: New York Press.

Gala RR \& Westphal U 1965 Corticosteroid-binding globulin in the rat: studies on the sex difference. Endocrinology 77 841-851.

Gala RR \& Westphal U 1966 Further studies on the corticosteroidbinding globulin in the rat: proposed endocrine control. Endocrinology 79 67-76.

Hannon R, Croxtall JD, Getting SJ, Roviezzo F, Yona S, Paul-Clark MJ, Gavins FN, Perretti M, Morris JF, Buckingham JC et al. 2003 Aberrant inflammation and resistance to glucocorticoids in annexin $1-/-$ mouse. FASEB Journal 17 253-255.

Homo-Delarche F, Fitzpatrick F, Christeff N, Nunez EA, Bach JF \& Dardenne M 1991 Sex steroids, glucocorticoids, stress and autoimmunity. Journal of Steroid Biochemistry 40 619-637.

Horlick KR, Cheng IC, Wong WT, Wakeland EK \& Nick HS 1991 Mouse lipocortin I gene structure and chromosomal assignment: gene duplication and the origins of a gene family. Genomics 10 365-374.

John CD, Christian HC, Morris JF, Flower RJ, Solito E \& Buckingham JC 2004 Annexin 1 and the regulation of endocrine function. Trends in Endocrinology and Metabolism 15 103-109.

Lo MJ, Chang LL \& Wang PS 2000 Effects of estradiol on corticosterone secretion in ovariectomized rats. Journal of Cellular Biochemistry 77 560-568.

Mitchner NA, Garlick C \& Ben-Jonathan N 1998 Cellular distribution and gene regulation of estrogen receptors $\alpha$ and $\beta$ in the rat pituitary gland. Endocrinology 139 3976-3983.

Morris JF, Omer S, Davies E, Wang E, John CD, Afzal T, Wain S, Buckingham JC, Flower RJ \& Christian HC 2006 Lack of annexin 1 results in an increase in corticotroph number in male but not female mice. Journal of Neuroendocrinology 18 835-846.

Moss SE \& Morgan RO 2004 The annexins. Genome Biology 5 219-227.

Mulla A, LeRoux C, Solito E \& Buckingham JC 2005 Correlation between the anti-inflammatory protein annexin 1 and serum cortisol in subjects with normal and dysregulated adrenal function. Journal of Clinical Endocrinology and Metabolism 90 557-562.

Nagashima AC, Giacomini D, Castro CP, Pereda MP, Renner U, Stalla GK \& Arzt E 2003 Transcriptional regulation of interleukin 6 in pituitary folliculo-stellate cells. Molecular and Cellular Endocrinology 201 47-56.

Omer S, Meredith D, Morris JF \& Christian HC 2006 Evidence for the role of ABCA1 in the externalization of annexin 1 from pituitary folliculo-stellate cells and ABCA1-transfected cell models. Endocrinology 147 3219-3227.

Ozawa H, Miyachi M, Ochiai I, Tsuchiya S, Morris JF \& Kawata M 2002 Annexin 1 immunoreactivity in the folliculo-stellate cells of the rat anterior pituitary: the effect of adrenalectomy and corticosterone treatment on its subcellular distribution. Journal of Neuroendocrinology 14 621-628.

Peiffer A \& Barden N 1987 Estrogen-induced decrease of glucocorticoid receptor messenger ribonucleic acid concentration in rat anterior pituitary gland. Molecular Endocrinology $1435-440$.

Peiffer A, Lapointe B \& Barden N 1991 Hormonal regulation of type II glucocorticoid receptor messenger ribonucleic acid in rat brain. Endocrinology 129 2166-2174.

Philip JG, John CD, Cover PO, Morris JF, Christian HC, Flower RJ \& Buckingham JC 2001 Opposing influences of glucocorticoids and interleukin- 1 beta on the secretion of growth hormone and ACTH in the rat in vivo: role of hypothalamic annexin 1. British Journal of Pharmacology 134 887-895.

Redei E, Li L, Halasz I, McGivern RF \& Aird F 1994 Fast glucocorticoid feedback inhibition of ACTH secretion in the ovariectomized rat: effect of chronic estrogen and progesterone. Neuroendocrinology 60 113-123.

Sanchez-Criado JE, Martin de las Mulas J, Bellido C, Aguilar R \& GarridoGracia JC 2005 Gonadotrope oestrogen receptor- $\alpha$ and $-\beta$ and 
progesterone receptor immunoreactivity after ovariectomy and exposure to oestradiol benzoate, tamoxifen or raloxifene in the rat: correlation with $\mathrm{LH}$ secretion. Journal of Endocrinology 184 59-68.

Schuurs AH \& Verheul HA 1990 Effects of gender and sex steroids on the immune response. Journal of Steroid Biochemistry 35 157-172.

Seale JV, Wood SA, Atkinson HC, Bate E, Lightman SL, Ingram CD, Jessop DS \& Harbuz MS 2004 Gonadectomy reverses the sexually diergic patterns of circadian and stress-induced hypothalamo-pituitary-adrenal axis activity in male and female rats. Journal of Neuroendocrinology 16 516-524.

Seale JV, Wood SA, Atkinson HC, Lightman SL \& Harbuz MS 2005 Organizational role for testosterone and estrogen on adult hypothalamicpituitary-adrenal axis activity in the male rat. Endocrinology 146 1973-1982.

Smith CL \& Hammond GL 1992 Hormonal regulation of corticosteroidbinding globulin biosynthesis in the male rat. Endocrinology 130 2245-2251.

Solito E, Froud K, Christian H, Morris J \& Buckingham J 2003 Effects of dexamethasone and oestradiol on annexin 1 expression. Endocrine Abstracts 6 P65.

Solito E, Christian HC, Festa M, Mulla A, Tierney T, Flower RJ \& Buckingham JC 2006 Post-translational modification plays an essential role in the translocation of annexin A1 from the cytoplasm to the cell surface. FASEB Journal 20 E677-E687.

Taylor AD, Loxley HD, Flower RJ \& Buckingham JC 1995 Immunoneutralisation of lipocortin 1 reverses the acute inhibitory effects of dexamethasone on the hypothalamo-pituitary adrenalocortical responses to cytokines in the rat in vitro and in vivo. Neuroendocrinology 62 19-31.

Taylor AD, Christian HC, Morris JF, Flower RJ \& Buckingham JC 1997 An antisense oligodeoxynucleotide to lipocortin 1 reverses the inhibitory actions of dexamethasone on the release of $\mathrm{ACTH}$ from rat pituitary tissue in vitro. Endocrinology 138 2909-2918.

Tierney T, Christian HC, Solito E, Morris JF, Flower R \& Buckingham JC 2003 The early delayed inhibitory action of glucocorticoids on ACTH release is mediated by juxtacrine acting annexin 1 from folliculo-stellate cells: evidence from a co-culture cell line model. Journal of Neuroendocrinology 15 1134-1143.

Traverso V, Christian HC, Morris JF \& Buckingham JC 1999 Lipocortin 1 (annexin I): a candidate paracrine agent localized in pituitary folliculostellate cells. Endocrinology 140 4311-4319.

Viau V \& Meaney MJ 1991 Variations in the hypothalamic-pituitary-adrenal response to stress during the estrous cycle in the rat. Endocrinology 129 2503-2511.

Viau V, Bingham B, Davis J, Lee P \& Wong M 2005 Gender and puberty interact on the stress-induced activation of parvocellular neurosecretory neurons and corticotrophin-releasing hormone messenger ribonucleic acid expression in the rat. Endocrinology 146 137-146.

Wallner BP, Mattaliano RJ, Hession C, Cate RL, Tizard R, Sinclair LK, Foeller C, Chow EP, Browning JL, Ramachandran KL et al. 1986 Cloning and expression of human lipocortin, a phospholipase A2 inhibitor with potential anti-inflammatory activity. Nature 320 77-81.

Whitacre CC, Dowdell K \& Griffen AC 1998 Neuroendocrine influences on experimental autoimmune encephalomyelitis. Annals of the New York Academy of Sciences 840 705-716.

Young EA, Altemus M, Parkison V \& Shastry S 2001 Effects of estrogen antagonists and agonists on the ACTH response to restraint stress in female rats. Neuropsychopharmacology 25 881-891.

\section{Received in final form 13 November 2006 \\ Accepted 15 November 2006 \\ Made available online as an Accepted Preprint 17 November 2006}

